\title{
Evaluation of Long-Term Effects of Levetiracetam Monotherapy on Hematological and Liver Function Parameters in Children with Idiopathic Epilepsy
}

\author{
Levetirasetam Monoterapisi Alan İdyopatik Epilepsili Çocuklarda \\ Hematolojik ve Karaciğer Fonksiyon Testlerinin Uzun Dönem \\ Etkilerinin Değerlendirilmesi
}

Beril DILBER1, Nihal YILDIZ1', Huseyin YAMAN², Tulay KAMASAK', Gulnur ESENULKU1', PInar KART OZKAN ${ }^{1}$, Elif ARSLAN ACAR ${ }^{1}$, Sevim SAHIN¹, Suleyman Caner KARAHAN², Ali CANSU ${ }^{1}$

1Department of Pediatric Neurology, Karadeniz Technical University, Trabzon, Turkey

2Department of Clinical Biochemistry, Karadeniz Technical University Faculty of Medicine, Trabzon, Turkey

\begin{abstract}
Objective: We aimed this study, investigated the changes in pre- and post-treatment hematological parameters, liver and kidney function parameters in children that were diagnosed with epilepsy and initiated on levetiracetam (LEV) therapy.

Material and Methods: The study population consisted of 114 children (6-18 years) had normal growth percentiles, that were treated for new-onset epilepsy with LEV monotherapy. In each patient, hematological parameters, B12, ferritin, liver and kidney function parameters were measured before and one/three years after the initiation of the therapy.

Results: The hemoglobin (Hgb) and hematocrit (Htc) levels showed a significant increase and the absolute lymphocyte count (ALC), absolute neutrophil count (ANC) ( $p=0.000)$, monocyte percentage ( $p=0.032)$, and mean platelet volume (MPV) ( $p=0.000$ ) levelsshowed a significant decrease. The ALC levels decreased significantly in 6 (5.3\%) children. The mean drug dose at three years of treatment was $30.0 \pm 5.6 \mathrm{mg} / \mathrm{kg} /$ day. No significant difference was found between preand post-treatment platelet (PLT) counts and no significant correlation was found between gender and hematological parameters ( $p>0.05$ for both).

Conclusion: Although LEV monotherapy led to changes in the hematological parameters of the epilepsy patients, no significant change was observed in liver function. We suggest that when evaluating the hematological parameters in children with epilepsy, the community's predisposition should be considered and also children should be examined for iron deficiency and vitamin B12 deficiency anemia before initiating the LEV therapy. It was also revealed that long-term LEV monotherapy is a safe treatment in children with epilepsy.
\end{abstract}

Key Words: Creatinine, Epilepsy, Hematological, Levetiracetam, Liver function tests

(10)

0000-0002-7633-0060 : DILBER B 0000-0003-0989-842X: YILDIZ N 0000-0003-4440-3912 : YAMAN H 0000-0002-5212-0149: KAMASAKT OD00-0002-0423-6078: ESENUHKU D000-0002-942-14078: KAMANULKU G D000-0001-5726-737X: KART OZKAN P 0000-0002-3284-107X: ARSLAN ACAR
$0000-0001-5415-5874$ : SAHIN S $0000-0001-5415-5874$ : SAHIN S
$0000-0001-5091-081 X:$ KARAHAN S 0000-0002-1930-6312 : CANSU A

\begin{abstract}
Conflict of Interest / Çıkar Çatışması: On behalf of all authors, the corresponding author states that there is no conflict of interest.
Ethics Committee Approval / Etik Kurul Onayı: This study was conducted in accordance with the Helsinki Declaration Principles. A written consent was obtained from the parent/guardian of each patient and the study was approved by the local ethics committee, Karadeniz Technical University, (2020/95).

Contribution of the Authors / Yazarların katkısI: DILBER B: Constructing the hypothesis or idea of research and/or article, Planning methodology to reach the Conclusions, Organizing, supervising the course of progress and taking the responsibility of the research/study, Taking responsibility in patient follow-up, collection of relevant biological materials, data management and reporting, execution of the experiments, Taking responsibility in logical interpretation and conclusion of the results, Taking responsibility in necessary literature review for the study, Taking responsibility in the writing of the whole or important parts of the study. YILDIZ $\mathbf{N}$ : Constructing the hypothesis or idea of research and/or article, Planning methodology to reach the Conclusions, Organizing, supervising the course of progress and taking the responsibility of the research/study, Taking responsibility in patient follow-up, collection of relevant biological materials, data management and reporting, execution of the experiments, Taking responsibility in logical interpretation and conclusion of the results, Taking responsibility in necessary literature review for the study, Taking responsibility in the writing of the whole or important parts of the study. YAMAN H: Organizing, supervising the course of progress and taking the responsibility of the research/study, Taking responsibility in the writing of the whole or important parts of the study. KAMASAK T: Taking responsibility in the writing of the whole or important parts of the study. ESENKULU G: Reviewing the article before submission scientifically besides spelling and grammar. KART OZKAN P: Reviewing the article before submission scientifically besides spelling and grammar. ARSLAN ACAR E: Taking responsibility in necessary literature review for the study. SAHIN S: Taking responsibility in logical interpretation and conclusion of the results. CANSU A: Organizing, supervising the course of progress and taking the responsibility of the research/study, Taking responsibility in patient follow-up, collection of relevant biological materials, data management and reporting, execution of the experiments, Taking responsibility in logical interpretation and conclusion of the results, Taking responsibility in necessary literature review for the study.

How to cite / Atıf yazım şekli : Dilber B, Yıldız N, Yaman H, Kamasak T, Esenulku G, Kart Ozkan P et al. Evaluation of Long-Term Effects of Levetiracetam Monotherapy on Hematological and Liver Function Parameters in Children With ldiopathic Epilepsy. Turkish J Pediatr Dis 2022;16:144-149.
\end{abstract}

Correspondence Address / Yazıșma Adresi:

Beril DILBER

Karadeniz Technical University,

Department of Pediatric Neurology, Trabzon, Turkey

E-posta: beriltem@gmail.com
Received / Geliş tarihi : :28.07.2021 Accepted / Kabul tarihi : 17.11.2021 Online published Elektronik yayın tarihi

DOI: 10.12956/tchd.975416 


\section{ÖZ}

Amaç: Bu çalışmada epilepsi tanısı ile levetirasetam (LEV) tedavisi bașlanan çocuklarda tedavi öncesi ve sonrası hematolojik parametreler, karaciğer ve böbrek fonksiyon parametrelerindeki değişiklikleri araşıımayı amaçlamışıı.

Gereç ve Yöntemler: Çalışma popülasyonu 6-18 yaş arasında normal büyüme hızına sahip yeni tanı epilepsisi olan, LEV monoterapisi başlanan 114 çocuktan oluşuyordu. Her hastada hematolojik parametreler, B12, ferritin, karaciğer ve böbrek fonksiyon parametreleri, tedavi başlangıcından önce ve bir/üç yıl sonra ölçüldü.

Bulgular: Hemoglobin ( $\mathrm{Hgb})$ ve hematokrit $(\mathrm{Htc})$ seviyelerinde anlamlı artış ve mutlak lenfosit sayıSI (ALC), mutlak nötrofil sayıSI (ANC) $(p=0.000)$, monosit yüzdesi $(p=0.032)$ ve ortalama trombosit hacmi görüldü. (MPV) $(p=0.000)$ seviyelerinde anlamlı düşüş görüldü. $A L C$

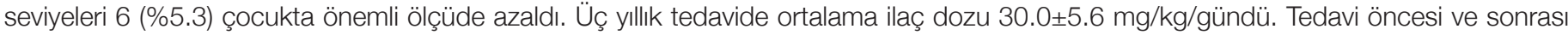
trombosit (PLT) sayıları arasında anlamlı bir fark bulunmadı ve cinsiyet ile hematolojik parametreler arasında anlamlı bir ilişki bulunmadı (her ikisi için $p>0.05)$.

Sonuç: LEV monoterapisi epilepsi hastalarının hematolojik parametrelerinde değişikliklere yol açsa da karaciğer fonksiyonlarında anlamlı bir değişiklik gözlenmedi. Epilepsili çocuklarda hematolojik parametreler değerlendirilirken toplumun yatkınlığının göz önünde bulundurulması ve ayrıca LEV tedavisine başlanmadan önce demir eksikliği ve B12 vitamini eksikliği anemisi olan çocukların da muayene edilmesi gerektiğini öneriyoruz. Ayrıca epilepsili çocuklarda uzun süreli LEV monoterapisinin güvenli bir tedavi olduğu ortaya çıktı.

Anahtar Sözcükler: Kreatinin, Epileps, Hematolojik, Levetiresetam, Karaciğer Fonksiyon Testleri

\section{INTRODUCTION}

Epilepsy disorders are the most common treatable neurological disorders in childhood. Diagnosis and treatment of these disorders has improved over time and antiepileptic drugs (AEDs) are commonly as the first line of treatment for seizure disorder (1). Levetiracetam (LEV) is a well-tolerated drug that is commonly used in the treatment of epilepsy due to its broad spectrum, low side-effect profile, and practicality (2-4). To date, there have been very few studies investigating long-term changes in hematological parameters in epilepsy patients receiving LEV therapy $(5,6)$. Although controversial findings have been presented in those studies, long-term effects of LEV on other systems have been rarely examined $(2,3)$. On the other hand, patients receiving LEV monotherapy have been shown to have significantly reduced platelet (PLT) counts and absolute lymphocyte counts (ALCs) (6). The present study, for the first time in the literature, investigated the changes in pre- and post-treatment hematological parameters, liver and kidney function parameters, and creatinine levels in children that were newly diagnosed with epilepsy and were initiated on LEV therapy.

\section{MATERIALS and METHODS}

A total of 277 children aged 6-18 years were newly diagnosed with epilepsy and received LEV monotherapy in our Pediatric Neurology department between 2015 and 2020. Exclusion criteria included ongoing treatment for anemia, blood transfusion, recent infections, progressive metabolic disease, and previous drug use due to febrile seizure. Hemogram parameters, AST, ALT, GGT, albumin, creatinine values and vitamin B12 and ferritin levels were examined in 277 patients enrolled in the study. 26 patients who had iron deficiency anemia (IDA) (ferritin<20 ml/ng), 33 patients had vitamin B12 deficiency (<200 pg/ml), 10 patients who used a secondary drug antiepileptic due to persistent seizures, and 8 patients who had abnormal findings on cranial computed tomography (CT) scan (cortical dysplasia, hydrocephalus, cyst, or mass), comprising 86 patients who were lost to follow-up were excluded from the study. The remaining 114 patients were included in the study. Of these, 114 children who had normal growth percentiles for body height and weight and had no anemia, no liver or renal insufficiency, no active drug use, and no progressive neurological diseases were included in the study. In each patient, hematological parameters, liver and kidney function parameters, electrolytes, and creatinine levels were measured before and three years after the initiation of the therapy.

Blood samples were obtained from each patient between 08.00 and 10.00 AM after 8-12 hours of fasting. Two $\mathrm{ml}$ of blood sample were collected in tubes containing ethylenediamine tetraacetic acid (EDTA) as an anticoagulant. Five $\mathrm{ml}$ of blood sample was collected into an EDTA-containing vacutainer and then injected to a serum separator tube with gel. In each patient, hematological parameters including hemoglobin ( $\mathrm{Hgb})$, hematocrit ( $\mathrm{Htc})$, mean corpuscular volume (MCV), mean corpuscular hemoglobin $(\mathrm{MCH})$, mean corpuscular hemoglobin concentration $(\mathrm{MCHC})$, mean platelet volume (MPV), lymphocyte count, neutrophil count, white blood cell count (WBC), absolute lymphocyte count (ALC), absolute neutrophil count (ANC), PLT count, vitamin B12, ferritin, aspartate aminotransferase (AST), alanine aminotransferase (ALT), gamma glutamyltransferase (GGT), and albumin were measured both before and one/three years after treatment. These parameters were evaluated based on the reference ranges for age and the parameters of hemogram that were below the $3^{\text {rd }}$ percentile for age were accepted as low. Blood parameters were measured using a Sysmex XN-1000 auto analyzer with original kits. ALT, AST, and GGT levels were measured using the enzymatic method and the albumin and creatinine levels were measured on a Beckman Coulter AU5800 auto analyzer using the colorimetric method with the original kits. In each patient, LEV therapy was initiated at a dose 
of $10 \mathrm{mg} / \mathrm{kg} /$ day and the dosage was increased up to $45 \mathrm{mg} / \mathrm{kg} /$ day until complete seizure control.

The normal reference ranges for age were as follows: Hgb: 6-12 years, 11.5-15.5 g/dl, 12-18 years (female) and 12.0-16.0 years (male), 13.0$16.0 \mathrm{~g} / \mathrm{dl}$; Htc: 6-12 years, 35-45\%, $12-18$ years (female), 36-46\%, 12-18 years (male), 37-49\%; MCV: 6-12 years, 77-95 fL, 12-18 years (female), 78-98 fL, 12-18 years (male), 78-102 fL; MPV: 6.5-12.0 fL;

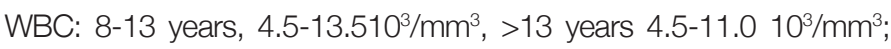
lymphocyte count: $1.500-3.000 \times 10^{3} / \mathrm{mm}^{3}$, neutrophil count: $3.000-$ $5.800 \times 10^{3} / \mathrm{mm}^{3}$, monocyte percentage: $285-500 \%$; ANS: $<1.500$ $\times 10^{3} / \mathrm{mm}^{3}$, and ALS: $<1.500 \times 10^{3} / \mathrm{mm}^{3}$.

For both genders, AST: 1-9 years, 15-55 IU/L, 10-19 years: 5-45 IU/L; ALT: 1-19 years, 5-45 IU/I; GGT: 10-15 years, 5-24 IU/L; albumin: 5-19 years, 4.0-5.3 g/dL; creatinine, 0.5-1.0 $\mathrm{mg} / \mathrm{dL}$ were accepted as the normal reference ranges (7).

A written consent was obtained from the parent/guardian of each patient and the study was approved by the local ethics committee, Karadeniz Technical University, (2020/95).

\section{Statistical analysis}

Statistical analyses were performed using the SPSS 23.0 (IBM Corp. Released 2015. IBM SPSS Statistics for Windows, Version 23.0, Armonk, NY: IBM Corp.). Continuous variables were expressed as mean \pm standard deviation (SD), minimum (min), and maximum (max) and categorical variables were expressed as frequencies (n) and percentages (\%). Normal distribution of continuous variables was assessed by One-Sample Kolmogorov Smirnov test and the all variables showed non-normal distribution. Dependent groups were compared using Wilcoxon test since the data did not show normal distribution. Chi-square test was used in the analysis of qualitative data. A p value of less than 0.05 was considered to show a statistically significant result.

\section{RESULTS}

Comparison of 277-height-healthy children with normal under the levetiracetam treatment and patients with anemia have been shown in Table I. The 114 children comprised 57 (50\%) boys and 57 (50\%) girls with a mean age of $10.95 \pm 2.84$ (range, 6-16) years. Sixty-nine $(60.5 \%)$ children had a history of focal seizures and 45 (39.5\%) of them had a history of generalized seizures. Twenty-eight (24.6\%) children had no family history of epilepsy. No patient had abnormal cranial findings on computed tomography (CT) (Table I).

No significant difference was found between pre- and posttreatment AST, ALT, GGT, albumin, and creatinine levels ( $p>0.05$ ). Similarly, no increase was observed in liver and kidney function parameters, no significant difference was found among the LEV doses administered, and no significant difference was found between the genders ( $p>0.05$ for all) (Table II).
Table I: Demographic and clinical characteristics.

\begin{tabular}{|c|c|c|}
$\begin{array}{c}\text { Patients that } \\
\text { started LEV } \\
\text { therapy }\end{array}$ & $\begin{array}{c}\text { Patients } \\
\text { continuing } \\
\text { LEV therapy }\end{array}$ & $\mathbf{p}$ \\
\hline 219 & 114 \\
\hline
\end{tabular}

\begin{tabular}{|l|c|c|c|}
\hline $\mathrm{n}$ & 219 & 114 & \\
\hline Age (years) & $11.85 \pm 1.96$ & $10.95 \pm 2.84$ & $>0.05$ \\
\hline Body weight $(\mathrm{kg})$ & $42.36 \pm 12.84$ & $39.58 \pm 15.47$ & $>0.05$ \\
\hline Body height $(\mathrm{cm})$ & $142.15 \pm 16.42$ & $140.21 \pm 22.10$ & $>0.05$ \\
\hline Gender (F/M) $(\mathrm{n})$ & $96 / 123$ & $57 / 57$ & $>0.05$ \\
\hline Family history of epilepsy & 32 & 28 & $>0.05$ \\
\hline $\begin{array}{l}\text { Seizure type (n) } \\
\text { Focal }\end{array}$ & 126 & 69 & 0.018 \\
Generalized & 93 & 45 & 0.016 \\
\hline
\end{tabular}

Vitamin B12 level $(\mathrm{pg} / \mathrm{ml}) \quad 185.28 \pm 22.16 \quad 238.96 \pm 36.290 .010$

\begin{tabular}{l|l|l|l} 
Ferritin level $(\mathrm{ml} / \mathrm{ng})$ & $28.93 \pm 22.65$ & $35.25 \pm 19.98$ & 0.025 \\
\hline
\end{tabular}

Tablo II: Pre- and post-treatment liver and kidney function parameters.

\begin{tabular}{|l|c|c|c|}
\hline & $\begin{array}{c}\text { Pretreatment } \\
(\mathbf{n = 1 1 4})\end{array}$ & $\begin{array}{c}\text { Posttreatment } \\
(\mathbf{n = 1 1 4})\end{array}$ & $\mathbf{p}$ \\
\hline AST $(\mathrm{IU} / \mathrm{l})$ & $24.1 \pm 8.32$ & $25.3 \pm 10.4$ & $>0.05$ \\
\hline ALT $(\mathrm{IU} / \mathrm{l})$ & $23.1 \pm 6.32$ & $30.1 \pm 6.32$ & $>0.05$ \\
\hline GGT $(\mathrm{IU} / \mathrm{l})$ & $13.1 \pm 2.57$ & $14.0 \pm 3.9$ & $>0.05$ \\
\hline Albumin $(\mathrm{g} / \mathrm{dl})$ & $4.4 \pm 0.32$ & $4.4 \pm 0.31$ & $>0.05$ \\
\hline Creatinine $(\mathrm{mg} / \mathrm{dl})$ & $0.86 \pm 0.38$ & $0.75 \pm 0.59$ & $>0.05$ \\
\hline
\end{tabular}

AST: Aspartate aminotransferase, ALT: Alanine aminotransferase, GGT: Gamma glutamyl transferase

However, a significant difference was found between pre- and posttreatment Hgb $(p=0.000)$, Htc $(p=0.002)$, ALC $(p=0.000)$, ANC $(p=0.000)$, monocyte percentage $(p=0.032)$, and MPV $(p=0.000)$ levels. Of these, the Hgb and Htc levels showed a significant increase while the ANS, ALS, monocyte percentage, and MPV levels showed a significant decrease (Table III). There was no found between pretreatment and post-treatment after one year.

No significant correlation was found between LEV dosage and the hematological and other parameters ( $p>0.05)$. Although the ALC levels were within the normal reference range for age before the treatment, they decreased significantly in 6 (5.3\%) children, including 5 girls and 1 boy with an ALC level of 0.83-1.41 x103/ $\mathrm{mm}^{3}(7)$. No patient had a history of frequent infections. The mean drug dose at three years of treatment was $30.0 \pm 5.6 \mathrm{mg} / \mathrm{kg} /$ day. On the other hand, no significant difference was found between pre- and post-treatment PLT counts and no significant correlation was found between gender and hematological parameters ( $p>0.05$ for both). 
Table III: Pre- and post-treatment hematological parameters.

\begin{tabular}{|c|c|c|c|c|}
\hline & $\begin{array}{l}\text { Pretreatment } \\
(n=114)\end{array}$ & $\begin{array}{l}\text { Posttreatment after } \\
\text { one year } \\
(n=114)\end{array}$ & $\begin{array}{c}\text { Posttreatment after } \\
\text { three year } \\
(n: 114)\end{array}$ & $\mathbf{p}$ \\
\hline Hematocrit (Hct) (\%) & $41.70 \pm 2.81$ & $41.98 \pm 3.00$ & $42.82 \pm 3.42$ & $0.002^{2}$ \\
\hline WBC $\left(10^{3} / \mathrm{mm}^{3} / \mu \mathrm{l}\right)$ & $8.63 \pm 3.36$ & $7.98 \pm 2.05$ & $8.04 \pm 2.50$ & $>0.05$ \\
\hline Lymphocyte (x103/mm³/ul) & $4.28 \pm 2.78$ & $4.88 \pm 2.08$ & $4.95 \pm 2.36$ & $>0.05$ \\
\hline $\operatorname{PLT}\left(10^{3} / \mu l\right)$ & $302.2 \pm 81.8$ & $295.8 \pm 72.54$ & $297.7 \pm 70.52$ & $>0.05$ \\
\hline Eosinophil $\left(\times 10^{3} / \mathrm{mm}^{3} / \mu \mathrm{l}\right)$ & $0.75 \pm 0.23$ & $0.98 \pm 0.49$ & $0.92 \pm 0.50$ & $>0.05$ \\
\hline Monocyte $\left(\times 10^{3} / \mathrm{mm}^{3} / \mu \mathrm{l}\right)$ & $0.63 \pm 0.28$ & $0.60 \pm 0.42$ & $0.33 \pm 0.27$ & $<0.001^{2}$ \\
\hline MCV (fl) & $88.28 \pm 12.24$ & $87.14 \pm 11.02$ & $89.12 \pm 11.12$ & $>0.05$ \\
\hline RDW (\%) & $13.77 \pm 0.94$ & $12.98 \pm 0.90$ & $13.18 \pm 0.92$ & $>0.05$ \\
\hline
\end{tabular}

WBC: White blood cell count, PLT: Platelet, MCV: mean corpuscular volume, ALC: Absolute lymphocyte count, ANC: Absolute neutrophil count, MPV: Mean platelet volume, RDW: Red blood cell distribution width. $\boldsymbol{p}^{\mathbf{1}}$ : between pretreatment and posttreatment after one year groups, $\boldsymbol{p}^{2}$ : between pretreatment and posttreatment after three year groups.

\section{DISCUSSION}

New-generation antiepileptics have become first-line therapies in pediatric patients due to their practicality, effective seizure control, low systemic effects, and low side-effect profiles (2). LEV is a broad-spectrum drug that has recently emerged as a popular drug in numerous seizure types. Moreover, LEV can be used comfortably and has been shown to provide effective seizure control $(3,4)$. The effects of commonly used antiepileptic drugs have been extensively investigated in the literature $(2,4)$. The present study, unlike previous studies, investigated the hematological parameters, liver and kidney function parameters, electrolytes, and creatinine levels in epilepsy children before and one/three years after treatment the LEV therapy. At three years of treatment, the $\mathrm{Hgb}$ and Htc levels showed a significant increase and the ALS, ANS, monocyte percentage, and MPV levels showed a significant decrease, whereas no significant difference was found in liver function parameters and creatinine levels.

Dinopoulos et al. (6) evaluated newly diagnosed epilepsy patients aged 2-15 years and reported that among the parameters measured before and after 2 and 6 months of the LEV therapy, only ALC showed a significant decrease at 6 months of the treatment. Attilakos et al. (5) evaluated 22 newly diagnosed epilepsy patients that received LEV monotherapy and indicated that the lymphocyte count showed a significant decrease, three children had lymphocyte counts below $10^{\text {th }}$ percentile for age, the neutrophil counts and the MCV and HTC levels showed significant increase, the PLT counts showed a significant decrease, and no significant difference was found in other parameters at 12 months of treatment. In our study, the mean age of the patients was higher and the patients were followed up for a longer period when compared to those reported in the studies mentioned above. Our findings indicated that although the ALC and ANC levels of the patients were significantly lower, the patients had no clinical complaints and their Hgb and Htc levels decreased at three years of treatment.

French et al. (4) evaluated adult patients that received LEV therapy and reported that the $\mathrm{Hgb}$ and $\mathrm{Htc}$ levels decreased significantly during the first month of the treatment than the second period in the patient group compared to the placebo group. The authors also noted although the WBC, neutrophil, lymphocyte, eosinophil, and monocyte levels decreased, they showed no significant difference and then returned to normal at three years of follow-up (4). Iron and vitamin B12deficiencies are commonly seen in the development countries $(8,9)$. Vitamin B12 is an essential vitamin naturally found in animal products, and people of any age can be deficient in this essential nutrient (9). In a study conducted in Turkey, vitamin B12 deficiency was detected in $60.8 \%$ of the neonates and in $76.7 \%$ of the mothers (9). However, there are controversial reports regarding the $\mathrm{Hgb}, \mathrm{Htc}, \mathrm{WBC}$, and MPV levels in who used LEV for epilepsy treatment $(5,6)$. The present study evaluated the hematological parameters in children aged 6-18 who received LEV monotherapy and had no anemia and, to our knowledge, this study is the first of its kind to investigate the vitamin B12 and ferritin levels in such patients. Bauer et al. evaluated 505 epilepsy patients that received LEV therapy and were followed up for a period of more than three years and reported that the laboratory parameters were highly stable and $4.6 \%$ of the patients had anemia, $4.8 \%$ had leukopenia, and 5.3\% had elevated GGT (10). Although pancytopenia has 
been reported in some patients receiving LEV therapy, there is no study reporting on the occurrence of pancytopenia during the long-term follow-up of the patients (11). Moreover, although LEVinduced eosinophilic pneumonia and B cell aplasia have been reported, there have been no reports of LEV-induced monocytic change $(12,13)$. Our findings indicated that the patients had no anemia and had increased $\mathrm{Hgb}$ and $\mathrm{Htc}$ levels at three years of LEV therapy; however, their MPV and WBC levels showed no significant difference, which could be associated with the hemoconcentration induced by LEV. Interestingly, the monocyte levels of the patients decreased at three years of treatment.

Levetiracetam therapy has been shown to change the PLT function and count $(6,14)$. Bachmann et al.(14) reported that the PLT counts decreased significantly in the patients receiving LEV therapy compared to control subjects at six months of treatment. In our study, however, no significant difference was found in the PLT counts of the patients while the MPV levels decreased significantly. Reduced PLT counts may be associated with vitamin B12 deficiency while reduced MPV levels may implicate that LEV leads to changes in PLT behavior.

Levetiracetam has a favorable pharmacological profile, can be completely absorbed after oral administration, and its metabolism is not dependent on the liver cytochrome P450 enzyme $(15,16)$. In patients receiving LEV therapy, liver function tests performed during the long-term follow-up are highly important for the assessment of the side effects and also for drug selection (16). The side effects of LEV on liver functions have been investigated in numerous studies $(4,14,17-20)$. French et al. (4) reported that $4.6 \%$ of the patients receiving LEV therapy had elevated liver enzyme levels compared to control subjects, although all the other parameters were within normal ranges. In another study, Bauer et al. detected elevated GGT levels in 5.3\% of the patients (10). In some other studies, LEV has been shown to be associated with fulminant hepatitis, though in a limited number of patients (19). In our patients, however, no significant change was observed in liver function parameters throughout the three-year follow-up period. Meaningfully, the significant decrease reported in other studies could be associated with the increased body weight of the patients. Moreover, those studies did not provide any information regarding the anthropometric measurements of the patients. In our study, no child had a body weight above the $97^{\text {th }}$ percentile. Accordingly, we suggest that children's body weight should be considered when evaluating their liver function parameters.

Levetiracetam is not extensively metabolized, and is predominantly excreted unchanged by the kidneys (21-23). Accordingly, dose adjustment is needed in patients with renal insufficiency (21). Moreover, LEV has been shown to cause interstitial nephritis and renal insufficiency (22). Contrariwise, in our study, the creatinine levels showed no significant change over the three-year follow-up period, which implicates that LEV has no renal side effects and thus LEV is a safe drug.

\section{CONCLUSION}

The results indicated that although LEV monotherapy led to changes in the hematological parameters of the epilepsy patients, it had no significant change on liver function parameters and creatinine levels and the patients had no clinical complaints. Based on these findings, we suggest that when evaluating the hematological parameters in children with epilepsy, the community's predisposition should be considered and also children with a normal growth percentile should be examined for iron deficiency anemia/ B12 deficiency before initiating the LEV therapy. Additionally, it was also revealed that long-term LEV monotherapy is a safe treatment in children with epilepsy. Further studies are needed to substantiate our findings.

\section{REFERENCES}

1. Kaeberle J. Epilepsy Disorders and Treatment Modalities. NASNSch Nurse 2018; 33: 342-4.

2. Tekgul H, Gencpinar P, Cavusoglu D, Dundar Olgac N. The efficacy, tolerability and safety of levetiracetam therapy in a pediatric population. Seizure 2016;36:16-21

3. Briggs DE, French JA. Levetiracetam safety profiles and tolerability in epilepsy patients. Expert Opin Drug Saf 2004;3:415-24.

4. French J, Edrich P, Cramer JA. A systematic review of the safety profile of levetiracetam: a new antiepileptic drug. Epilepsy Res 2001;47:77-90.

5. Attilakos A, Dinopoulos A, Paschalidou M, Tsirouda M, Karalexi M, Prasouli A, et al. Long-term effect of levetiracetam monotherapy on haematological parameters in children with epilepsy: A prospective study. Epilepsy Res 2018;145: 160-2.

6. Dinopoulos A, Attilakos A, Paschalidou M, Tsirouda M, Garoufi A, Moustaki M, et al Short-term effect of levetiracetam monotherapy on haematological parameters in children with epilepsy: a prospective study. Epilepsy Res 2014;108: 820-3.

7. Behrman Richard E, Kliegman Robert M, Jenson Hal B. Nelson textbook of pediatrics. 17 th ed. Elsevier, Philadelphia 2003;p:2393420.

8. Çoban S, YılmazKeskin E, Ĭğde M. Association between Maternal and Infantile Markers of Cobalamin Status during the First Month Post-Delivery. Indian J Pediatr 2018;85:517-22.

9. Moy RJ. Prevalence, consequences and prevention of childhood nutritional iron deficiency: A child public health perspective. Clin Lab Haematol 2006; 28:291-8.

10. Bauer J, Ben-Menachem E, Krämer G, Fryze W, Da Silva S, Kasteleijn-Nolst Trenité DG. Levetiracetam: a long-term follow-up study of efficacy and safety. Acta Neurol Scand 2006; 114: 16976.

11. Aydoğan $H$, Yalçn S, Karahan MA, Büyükfrat E. Pancytopenia associated with levetiracetam treatment in Lafora's disease. Blood Coagul Fibrinolysis 2012;23:175

12. Ozdemir H, Sumer S, Karabagli H, Akdemir G, Caliskaner AZ, Artac $\mathrm{H}$. B cell aplasia and hypogammaglobulinemia associated with levetiracetam. Ann Saudi Med 2018; 38:65-8.

13. Fagan A, Fuld J, Soon E. Levetiracetam-induced eosinophilic pneumonia. BMJ Case Rep 2017: 2017:bcr2016219121. 
14. Bachmann T, Bertheussen KH, Svalheim S, Rauchenzauner M, Luef G, Gjerstad L, et al. Haematological Side Effects of Antiepileptic Drug Treatment in Patients With Epilepsy. Acta Neurol Scand Supp 2011;191: 23-7.

15. Lyseng-Williamson KA. Levetiracetam: a review of its use in epilepsy. Drugs 2011; 71: 489-514.

16. Grosso S, Cordelli DM, Franzoni E, Coppola G, Capovilla G, Zamponi N, et al. Efficacy and safety of levetiracetam in infants and young children with refractory epilepsy. Seizure 2007;16:345-50.

17. Vidaurre J, Gedela S, Yarosz S. Antiepileptic Drugs and Liver Disease. Pediatr Neurol 2017;77:23-36.

18. Sethi NK, Sethi PK, Torgovnick J, Arsura E, Cukierwar F. Asymptomatic elevation of liver enzymes due to levetiracetam: a case report. Drug Metabol Drug Interact 2013; 28: 123-4.
19. Broli M, Provini F, Naldi I, Bisulli F, Sama C, Baruzzi A, et al. Unexpected gamma glutamyltransferase rise increase during levetiracetam monotherapy. Epileptic Disord 2010; 12: 81-2.

20. Tan TC, de Boer BW, Mitchell A, Delriviere L, Adams LA, Jeffrey GP, et al. Levetiracetam as a possible cause of fulminant liver failure. Neurology 2008; 71: 685-6.

21. Hurwitz KA, Ingulli EG, Krous HF. Levetiracetam induced interstitial nephritis and renal failure. Pediatr Neurol 2009; 41: 57-8.

22. Nau KM, Divertie GD, Valentino AK, Freeman WD. Safety and efficacy of levetiracetam for critically ill patients with seizures. Neurocrit Care 2009; 11: 34-7.

23. Abou-Khalil B. Levetiracetam in the treatment of epilepsy. Neuropsychiatr Dis Treat 2008; 4: 507-23. 